\title{
Urbanismo português na cidade de Maputo: passado, presente e futuro
}

\author{
Portuguese urbanism in the city of Maputo: past, present and future
}

Vanessa de Pacheco Melo

Arquiteta e doutoranda, investigadora do Grupo de Estudos Socioterritoriais Urbanos e de Ação Local (GESTUAL) do Centro de Investigação em Arquitetura, Urbanismo e Design (CIAUD) da Faculdade de Arquitetura da Universidade Técnica de Lisboa (FAUTL), Lisboa - Portugal, e-mail: vanessa.p.melo@gmail.com

\section{Resumo}

O urbanismo português caracteriza-se por um conjunto de princípios urbanísticos e processos de concepção e implementação que se foram moldando ao longo de diversos contextos e geografias, veiculando um consórcio de ideias urbanas sob o qual se construiu a identidade comum da "cidade portuguesa". Por meio da análise histórica do desenvolvimento da capital moçambicana, Maputo, e do urbanismo português nela patente desde a sua génese, procura-se entender em que consistiu em contexto africano este urbanismo, bem como qual o significado e o papel presente e futuro desta herança. Em Maputo, predominam atualmente diversas e extensas áreas semiurbanizadas sem as devidas condições de habitabilidade, habitadas pela maioria da população, tendencialmente de baixos recursos, que pouco evidenciam a influência do urbanismo português, ainda hoje presente no centro urbanizado. Atendendo às particularidades socioeconómicas, culturais e políticas dessa cidade, esse urbanismo revela-se descontextualizado e desadequado, principalmente em face das especificidades e dos problemas das suas áreas semiurbanizadas, que carecem de um novo modelo urbano. Alguns dos seus princípios e processos poderiam contribuir para a procura desse modelo, mas o seu papel presente e futuro assume maior significado ao nível da memória e da cultura, conferindo a Maputo uma identidade singular, só presente em outras cidades lusófonas da África Austral. A permanência dessa herança torna-se, contudo, incerta, diante do crescente número de intervenções desenvolvidas no atual contexto de globalização e economia neoliberal dominante, que rompem com as suas lógicas pelas mãos de uma multiplicidade de atores, portadores de variadas influências, lusófonas ou não.

Palavras-chave: Urbanismo português. Maputo. Áreas semiurbanizadas. Centro urbanizado. Atores do desenvolvimento urbano. 


\section{Abstract}

The Portuguese urbanism is characterised by a set of urban principles and processes of conception and implementation, shaped through various contexts and geographies, conveying a consortium of urban ideas under which the common identity of the "Portuguese city" has been constructed. The historical analysis of the development of the Mozambican capital, Maputo, and of the Portuguese urbanism present in it since its genesis, seeks to understand in what consisted this urbanism in African context, as well as the meaning and the present and future role of this heritage. Currently in Maputo, predominate diverse and extensive semiurbanized areas without adequate living conditions, inhabited by the majority of the population, generally low income, which show little evidence of the Portuguese urbanism influence, still present in the urbanized centre. Given the socioeconomic, cultural and politic particularities of this city, this urbanism proves to be out of context and unsuitable, manly regarding the specificities and problems of its semiurbanized areas, to which is necessary a new urban model. Some of its principles and processes could contribute to the search of such model, but its present and future role assumes greater significance in terms of memory and culture, giving a unique identity to Maputo, only present in other Lusophone cities in Southern Africa. Yet, the permanence of this heritage becomes uncertain, given the growing number of interventions developed in the current globalization context and dominant neoliberal economy, which break with its logics at the hands of a multiplicity of actors, conveyers of varied influences, Lusophone or not.

Keywords: Portuguese urbanism. Maputo. Semiurbanized areas. Urbanized centre. Urban development actors.

\section{Introdução}

A influência do urbanismo português sobre as cidades das antigas colónias lusas é incontornável e Rossa (2002, p. 195) refere mesmo que à "partida só o «sim» é a resposta para a questão - há uma «cidade portuguesa»?". Teixeira e Valla (1999, p. 215) mencionam que, apesar das características particulares de cada cidade colonial e da aparente casualidade como se estruturaram e desenvolveram, os modelos e tradição urbanos de referência partilhados asseguraram uma identidade formal e estrutural comum, conferindo-lhes "um inquestionável carácter português". Todavia, não é claro em que consiste esse urbanismo português, nomeadamente no que respeita à sua periodização e progressiva alteração das suas características, quer em função de diferentes momentos históricos, quer por influência de modelos urbanísticos estrangeiros. Teixeira (1993) menciona que essas dificuldades podem dever-se ao atraso da história urbana portuguesa em relação à europeia e americana, e Rossa (2002) relaciona-as principalmente com a diversidade de contextos em que o urbanismo português se desenvolveu, num período de tempo longo e num território vasto.
As dificuldades na definição do urbanismo português influenciam por sua vez a determinação do seu papel no desenvolvimento dessas cidades e da sua eventual permanência no contexto atual, bem como da sua pertinência e adequação às necessidades e problemas urbanos que hoje se fazem sentir. 0 presente artigo retoma essa problemática em contexto africano, por meio da análise da cidade de Maputo, procurando responder às questões: Qual é o significado do urbanismo português na cidade atual? Que relação pode estabelecer com o seu desenvolvimento futuro?

Parte-se da análise histórica do desenvolvimento de Maputo, estruturada em dois momentos: o que se inicia com a sua génese e abrange todo o período colonial português em Moçambique, e o que começa após a independência deste país, em 1975, e se prolonga até hoje. No primeiro enquadra-se o desenvolvimento desta capital no contexto do urbanismo português e analisa-se a evolução das características de ambos ao longo do tempo, identificando as transformações operadas e as marcas deixadas. Com o afastamento da influência direta de Portugal sobre a cidade após a independência, apresenta-se a forma como Maputo se continuou a desenvolver à luz dos seus problemas mais 
prementes, identificando-se os atores envolvidos. 0 confronto das situações encontradas nestes dois momentos serve de base à reflexão sobre o papel do urbanismo português na cidade presente e futura e sobre a sua relação com o diversificado consórcio de ideias urbanas no mundo atual de língua portuguesa em África.

\section{Urbanismo português e desenvolvimento da cidade de Maputo}

\section{A cidade colonial de Lourenço Marques ${ }^{1}$}

A fixação portuguesa em Lourenço Marques iniciou-se com a criação de um presídio em 1781, mas "só se efectivou depois de 1805 com a chegada de uma força militar" e a constituição de "uma pequena povoação fortificada, para quartel e feitoria, que ocupava [...] uma língua de areia, de cerca de 1200 metros de comprimento e 100 metros de largura, rodeada de pântanos" (MENDES, 1985, p. 7980). O seu surgimento no contexto do urbanismo português da fase de expansão ultramarina é tardio, uma vez que a ocupação das ilhas atlânticas se deu no século XV e o processo de urbanização do Brasil se iniciou com a fundação da cidade de São Salvador da Baia em meados do século XVI. Rossa (2002, p. 371) refere que só muito mais tarde houve interesse e meios para colonizar o "extenso bordo afro-asiático que vai do Sahara até Diu”, através de "estabelecimentos militares de apoio à navegação e controlo hegemónico dos mares". Morais (2001) menciona que a ocupação se dava em pontos estratégicos das zonas costeiras, em Lourenço Marques com o objetivo de dominar o território ao sul do rio Save, sob a forma de presídios que guardavam a rota marítima da Índia.

Apesar do seu surgimento tardio, o primeiro povoado de Lourenço Marques evidencia características semelhantes às de outras estruturas urbanas que surgiram no período de expansão. Rossa (2002) refere que estas denotam a existência de uma escola portuguesa de urbanismo, cujo radical foi a engenharia militar, baseada num
«Método Lusitânico» e síntese entre a tradição, a presença espanhola e o contributo de engenheiros militares franceses e holandeses. Teixeira e Valla (1999) acrescentam ainda a influência das novas concepções teóricas renascentistas no campo do urbanismo, assim como da experiência científica e dos conhecimentos desenvolvidos pelos matemáticos e cosmógrafos das descobertas marítimas. Para Rossa (2002, p. 380), o urbanismo português deste período resulta da formulação de leis e posturas e é "regulado por via processual e descritiva com base numa fortíssima tradição demarcadora". Segundo Teixeira e Valla (1999, p. 48), os construtores não levavam necessariamente "planos desenhados ou instruções específicas sobre a fundação das cidades" e, na maioria dos casos, os modelos de referência eram conhecidos empiricamente e adaptados às condições locais. A aplicação desses modelos não originou tipos puros de traçado, surgindo "padrões urbanos de origem vernácula ou medieval sintetizados com ideais renascentistas" (TEIXEIRA; VALLA, 1999, p. 216).

Essas características associam-se a outras, que podem identificar-se na planta da povoação de Lourenço Marques de 1876 e no descrito por Mendes (1985) e Morais (2001). A escolha do local de implementação, numa baía abrigada virada a sul, com boas condições de porto natural e protegida por um promontório, é um dos aspectos mencionados por Teixeira e Valla (1999), ao qual pode acrescentar-se: o traçado geométrico regular adaptado à topografia, mas não racionalizado; o protagonismo urbanístico da rua, em que as vias principais mais largas se dispõem paralelamente à costa, desenhando uma estrutura de quarteirões lineares, com rua de ambos os lados, idênticos aos do período medieval; a existência de uma praça estruturante de cariz mais renascentista, articulando as vias e o acesso da língua de areia à margem continental, onde se localizam os equipamentos prioritários, apresentando uma constância e interação espacial; o espaço hierarquizado e a independência morfológica relativamente ao cerco muralhado (ROSSA, 2002; TEIXEIRA; VALLA, 1999). A Figura 1 sobrepõe a planta de $1876 \mathrm{com}$ a atual, identificando os

\footnotetext{
1 Lourenço Marques é o nome da capital moçambicana durante o período colonial, que passa a designar-se de Maputo depois da independência de Moçambique, tomando o nome do Rio Maputo que nela desagua.
} 


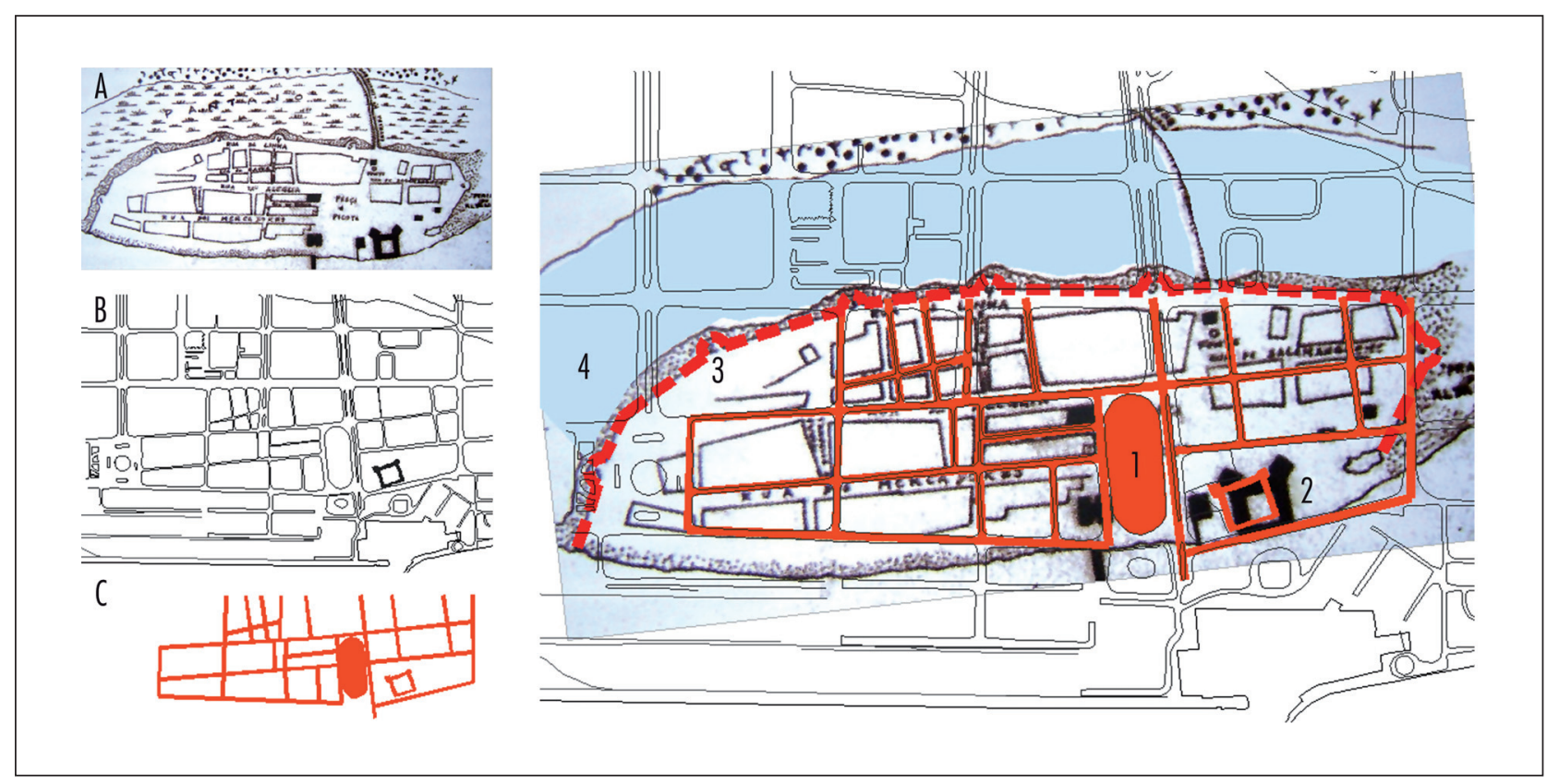

Figura 1 - Lourenço Marques em 1876 e Maputo atualmente

Legenda: 1 = Praça da Picota (atual Praça 25 de Junho); 2 = Fortaleza; 3 = Linha de defesa; 4 = Pântano; $A=$ Lourenço Marque (1876); B = Maputo (2012); C = Elementos urbanos permanecentes.

Fonte: Figura elaborada pela autora com base em cartografia disponibilizada pela Faculdade de Arquitetura e Planeamento Físico da Universidade Eduardo Mondlane (FAPF-UEM) e em fotografia da planta de Lourenço Marques de 1876, em MORAIS, 2001, p. 63.

elementos urbanos permanecentes, embora alguns reconfigurados.

Em 1887, Lourenço Marques é elevada a cidade e em 1898 a capital da Província Ultramarina de Moçambique. Essas mudanças devem-se a fatores como: a localização numa baía de fácil acesso em qualquer época do ano e a posição estratégica de entrada no território sul-africano, que decretaram o importante papel que o porto desempenharia; a descoberta de ouro em Lidemburgo, em 1873; e eventos políticos - a proclamação da sentença arbitral de Mac-Mahon, em 1875, que reconhece a soberania portuguesa sobre Lourenço Marques contra as pretensões da Inglaterra; a anexação do Transval por esta última, em 1877 (MENDES, 1985); e a definição das fronteiras desta região na Conferência de Berlim, em 1885 (ENDERS, 1997).

Em 1887, surge o primeiro plano de urbanização da cidade $^{2}$, que procurava a modernização do território africano, através duma política de obras públicas ao nível das infraestruturas, e que continuava a basear-se na engenharia militar (MORAIS, 2001). Este é influenciado pelos planos de desenvolvimento urbano que surgiram na "Metrópole" na segunda metade do século XIX, particularmente os de Lisboa, de Ressano Garcia, que procuravam dar resposta às situações criadas pela Revolução Industrial: um forte crescimento urbano gerado pelo grande afluxo de população maioritariamente rural, a introdução de novas funcionalidades e necessidades de saneamento e provisão de infraestruturas adequadas (viárias, ferroviárias, portuárias e de abastecimento de água, eletricidade e gás). Esses planos, muito influenciados pelos de Haussmann em Paris (LÔBO, 1995), introduziram alterações às práticas urbanísticas antecedentes, tais como: uma escala maior de intervenção e de traçado, uma geometria ortogonal mais assumida

\footnotetext{
${ }^{2}$ Segundo Morais (2001), embora este plano venha assinado pelo major de artilharia António José de Araújo, o papel determinante do líder da equipa desta expedição de obras públicas, o major e engenheiro Joaquim José Machado, levou algumas fontes a apontar ambos como autores, em regime de coautoria.
} 
e o surgimento de novos elementos urbanos, como os parques e os jardins.

A Figura 2 sobrepõe o plano de 1887 com o traçado atual da cidade. A sua observação e o descrito por Mendes (1985) e Morais (2001) evidenciam algumas dessas características, além de outras que permanecem associadas ao urbanismo português anterior, tais como: (1) uma expansão que dá continuidade por via do traçado à estrutura preexistente (determinando a secagem dos pântanos envolventes) e mantém a orientação do traçado paralelo à costa, propondo alterações pontuais da malha antiga, como a regularização de vias e do edificado e a demolição da linha de defesa; (2) adaptação à topografia, propondo a extensão do núcleo antigo ao nível do mar mediante a ocupação de uma área de menor declive, que estabelece a ligação com a zona de planalto entre os 40 e os 50 metros $^{3}$; (3) implementação de estratégias do uso e ocupação do solo, por via dum traçado regular em quadrícula, a que se submete a prática edificatória e se adapta às preexistências e à topografia; (4) criação de um espaço hierarquizado através de vias de diferentes larguras e da sua articulação com espaços públicos estruturantes, como parques e praças, onde se localizam equipamentos importantes; e (5) relação entre um traçado formal e certa informalização de ocupação, sendo os quarteirões delimitados, mas não edificados. Portas (2005, p. 20) refere que a escolha do traçado ortogonal deve-se à sua "adaptabilidade - ou indiferença - aos diferentes sítios, assegurando desde logo uma distribuição equitativa dos

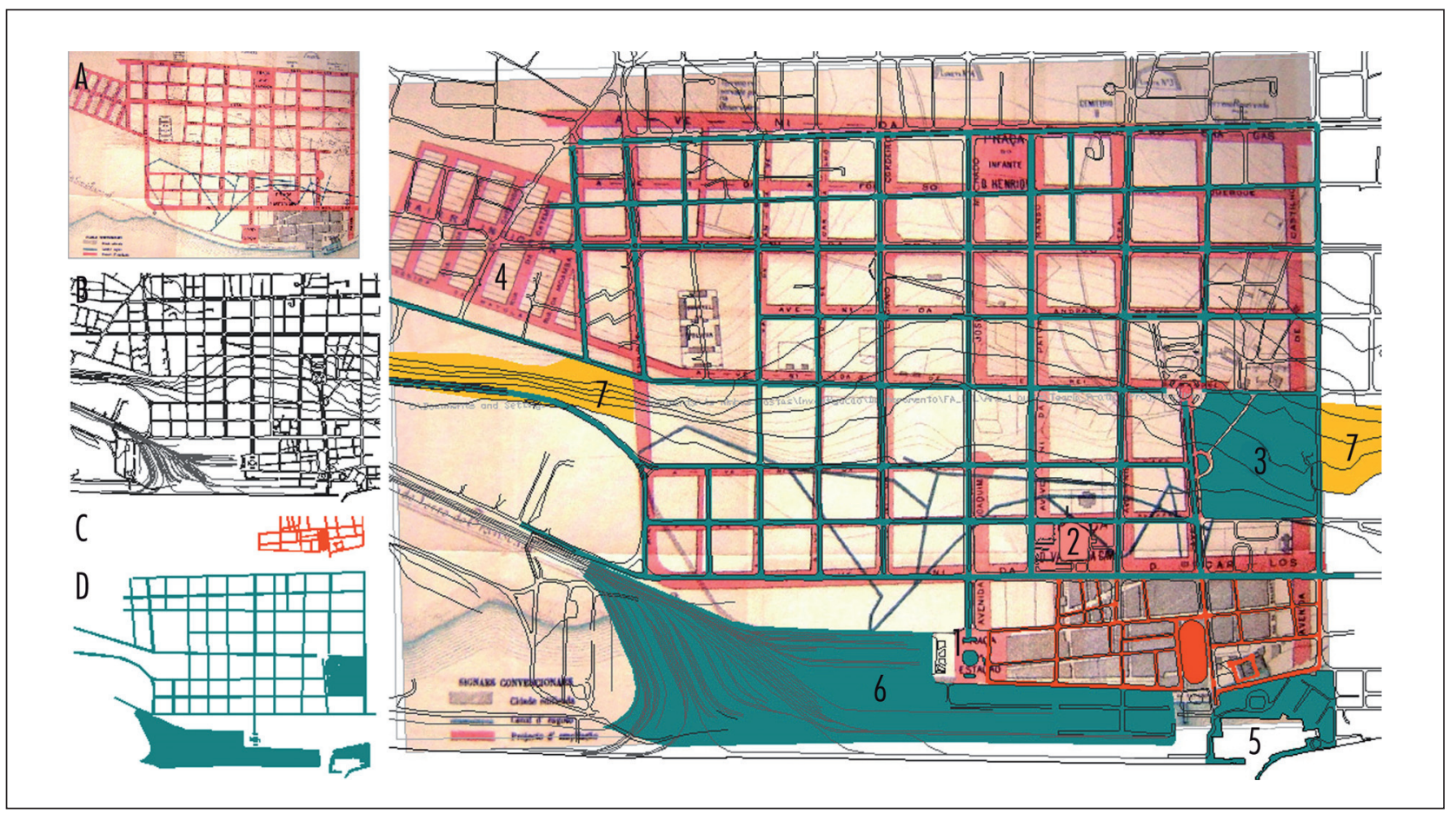

Figura 2 - Plano de Lourenço Marques em 1887 e Maputo atualmente

Legenda: 1 = Praça da Estação (atual Praça dos Trabalhadores) junto à estação do caminho-de-ferro; 2 = Praça D. Vasco da Gama, centro da nova cidade, destinado a edifícios públicos de relevo (atual mercado central); 3 = Jardim Vasco da Gama (atual Jardim Tunduro); 4 = Bairro indígena; 5 = Porto; 6 = Caminho-de-ferro; 7 = Áreas de declive acentuado; A = Lourenço Marques (1887); $B=$ Maputo (2012); $C=$ Elementos urbanos permanecentes (1876); $D=$ Elementos urbanos permanecentes (1887).

Fonte: Figura elaborada pela autora com base em cartografia disponibilizada pela FAPF-UEM e em fotografia do plano de Lourenço Marques de 1887, em MORAIS, 2001, p. 87

3 Embora a topografia do lugar tenha sido determinante para a elaboração do plano de urbanização, este foi também condicionado por questões políticas, nomeadamente os compromissos entre o Governo de Lisboa e a República da África do Sul, e pelo facto de os terrenos a oriente estarem concedidos a estrangeiros (MENDES, 1985; MORAIS, 2001). Esses aspectos estarão também presentes em planos de urbanização posteriores. 
lotes urbanos ou das quintas suburbanas e uma fácil reprodução face às necessidades de extensão", ressaltando uma "preocupação com os lotes de terreno e as edificações e o apelo a que se deixassem ruas largas e direitas". O plano de 1887 prevê ainda a criação de um pequeno bairro indígena que não foi construído. Essa população era geralmente pouco considerada nos planos de urbanização da cidade colonial, a qual habitava marginalmente, em assentamentos periféricos, junto às vias principais, sem infraestruturas e com carácter semirrural (MORAIS, 2001), aqui denominados semiurbanizados.

Até meados do século XX, o desenvolvimento de Lourenço Marques está associado à economia ferro-portuária e sul-africana, dando-se a um ritmo mais ou menos lento. Entre 1900 e 1940, a cidade cresce para norte e oeste de forma faseada, seguindo vários projetos de ampliação que refletem os mesmos princípios urbanísticos do plano de 1887; destacam-se algumas intervenções pontuais nas áreas consolidadas, como a Praça Mousinho de Albuquerque (atual Praça da Independência, onde se localiza o Conselho Municipal e a Catedral) e a ocupação da Praça D. Vasco da Gama pelo mercado central. Trata-se também de um período de consolidação das estruturas públicas - surgem novos equipamentos de vulto, como o Hospital Central - e de áreas meramente residenciais, acentuando-se a separação entre diferentes usos do solo, que remete para outra característica do urbanismo português, nomeadamente uma ocupação diferenciada segundo cotas altimétricas: a cidade alta, mais fresca e arejada, destinada aos edifícios administrativos, às principais instituições cívicas e religiosas e às residências das classes mais altas; e a cidade baixa, destinada às atividades marítimas, aos serviços e ao comércio, bem como às classes mais baixas, junto ao porto e aos locais de emprego (MENDES, 1985; MORAIS, 2001; TEIXEIRA; VALLA, 1999).

É durante esse período que se consolidam também as áreas semiurbanizadas, apelidadas de "caniço", material em que era então construída a maioria das suas habitações, por oposição à "cidade de cimento" urbanizada. Segundo Morais (2001), a existência desses assentamentos está contemplada pela legislação respeitante ao edificado pelo menos desde 1912, mas a sua crescente expansão para norte e nordeste da cidade era tida com apreensão, pelo que na década de 1930 o Município proíbe a utilização de formas construtivas de carácter permanente. Na tentativa de "estabelecer uma 'ordem' nos subúrbios [...] ainda só densamente ocupados junto à estrada de Circunvalação", surgem os bairros de Xipamanine e Munhuana, "marcados por um traçado regulador": o do primeiro, semelhante ao dos bairros indígenas e idêntico ao projetado no plano de 1887, equaciona "numa atitude colonial, a problemática da logística dos autóctones"; e o do segundo, "um traçado mais complexo, radial, centrado numa praça circular que constitui o centro da estrutura pública do bairro" (idem, p. 149-150). Na Figura 3, onde se sobrepõe a planta de Lourenço Marques em 1940 com o traçado da cidade atual, assinalam-se alguns dos aspectos referidos e procura-se identificar aproximadamente o "caniço", dado que, segundo Morais (2001), entre 1915 e 1940 os levantamentos que o contemplam são poucos ou incompletos.

A partir da década de 1950, em pleno período do Estado Novo, inicia-se uma política colonial marcada pela abertura ao capital estrangeiro, da qual resultam novas iniciativas e projetos industriais e agrários; e pela implementação de medidas que procuram atenuar as tensões sociais existentes, como a abolição do indigenato e do trabalho forçado (CABRAL, 2005), que não são alheias à luta armada pela independência iniciada em 1964. Mendes et al. (2005) referem que, durante esse período, o Estado português incentivou a migração de colonos para Moçambique, para uma maior ocupação e controlo do território, que resultou na criação e crescimento de inúmeros aglomerados com função administrativa e no desenvolvimento de projetos agrícolas sob forma de colonatos, justificando também o surgimento de atividades industriais nos meios urbanos, em face do aumento da população colona e das necessidades de consumo.

Em termos urbanísticos, a política do Estado Novo promoveu a concretização de espaços que consolidassem a imagem do poder e do regime. À semelhança do urbanismo português dos períodos anteriores, o traçado permanece como elemento regulador do preexistente e das novas áreas a urbanizar, produzindo um espaço hierarquizado, no qual as praças, parques e jardins assumem um papel estruturante, mas verificam-se também diferenças. Algumas destas decorrem da influência de urbanistas estrangeiros convidados a trabalhar na "Metrópole", como Alfred Donat-Agache 

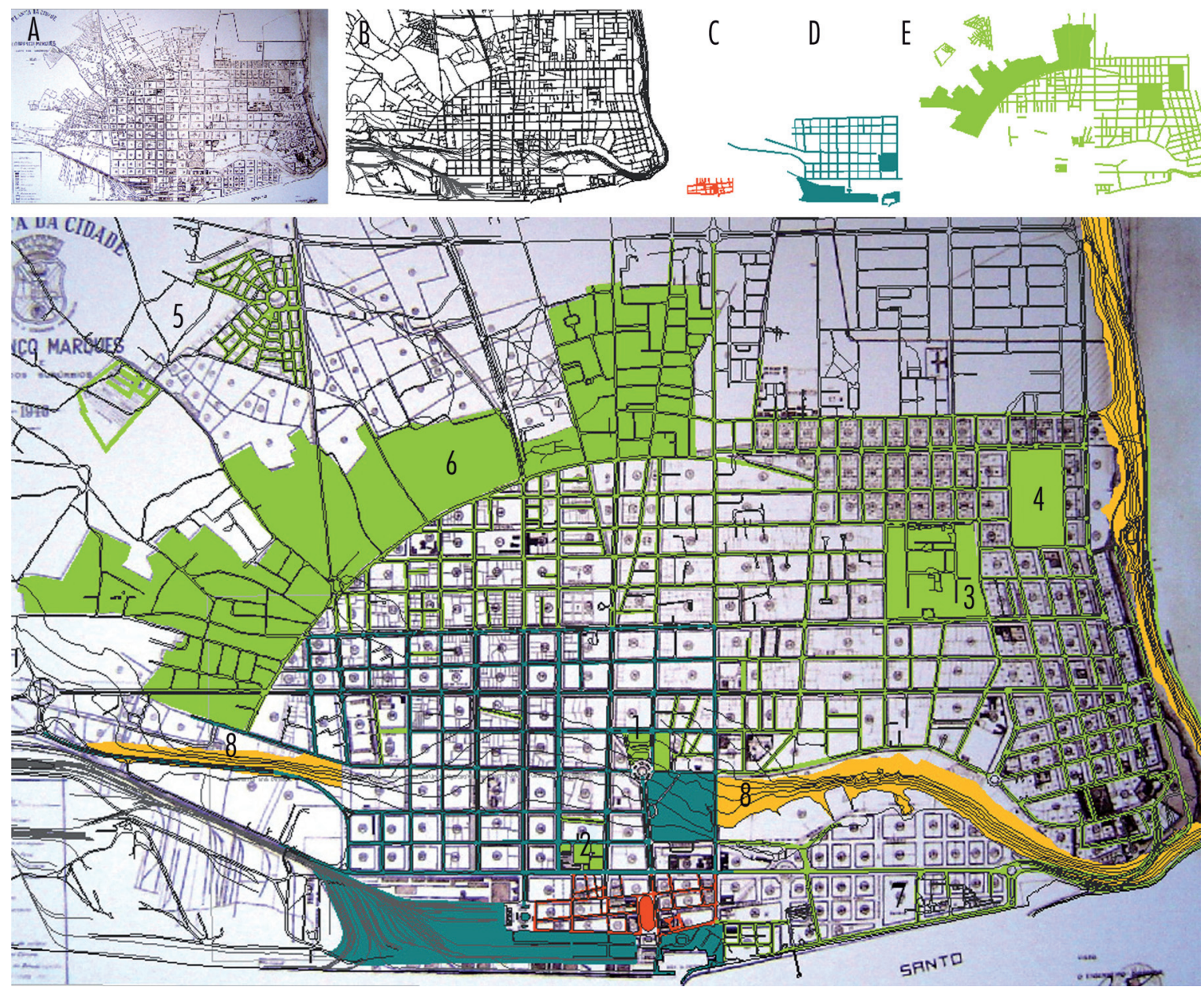

Figura 3 - Planta de Lourenço Marques em 1940 e Maputo atualmente

Legenda: 1 = Praça Mousinho de Albuquerque (atual Praça da Independência); 2 = Mercado Central; 3 = Hospital Central; 4 = Parque José Cabral (atual Parque dos Continuadores); 5 = Bairros de Xipamanine e Munhuana; 6 = Áreas semiurbanizadas (aproximação); 7 = Área planeada mas não construída; 8 = Áreas de declive acentuado; $A=$ Lourenço Marques (1940); $B=$ Maputo (2012); $C=$ Elementos urbanos permanecentes (1876); $D=$ Elementos urbanos permanecentes (1887); $E=$ Elementos urbanos permanecentes (1940).

Fonte: Figura elaborada pela autora com base em cartografia disponibilizada pela FAPF-UEM, em fotografia da planta de Lourenço Marques em 1940, em Morais (2001, p. 137) e nas figuras 29 e 29A, em MENDES, 1985, p. 94-95.

e Etienne de Gröer, que introduzem, entre outros aspectos: uma visão regional do planeamento, em que grandes áreas urbanas se articulam através de uma rede viária principal; a aplicação do zonamento às expansões urbanas e os princípios urbanísticos da cidade-jardim; assim como consolidam o desenho urbano formal e a valorização do espaço público (LÔBO, 1995).

É nesse contexto que surge, em 1952, o Plano Geral de Urbanização de Lourenço Marques, elaborado pelo arquiteto João Aguiar, subdiretor do Gabinete de Urbanização Colonial, no qual este panorama se manifesta de várias formas: (1) surge um zonamento funcional primário, evidenciando-se áreas administrativas, de serviços, comércio, habitação e lazer; (2) distinguem-se espaços e equipamentos públicos mais importantes, dotados de escala monumental à imagem da grandiosidade e ordem do Estado, e espaços habitacionais de escala mais comedida, em que predomina a habitação unifamiliar isolada, com reminiscências rurais (COSTA, 2002; MORAIS, 2001); (3) o traçado regulador abandona a ortogonalidade e as vias 
principais que articulam os espaços desenham novas direções; e (4) a lógica dos quarteirões é desmontada e distorcida, surgindo vias sinuosas e impasses, que continuam, todavia, confinada à geometria do traçado.

Esse plano-imagem nunca chega a implementar-se na totalidade; segundo Morais (2001), por limitações técnicas e administrativas, podendo acrescentar-se a dificuldade financeira. Conforme as suas propostas, traçam-se apenas algumas vias principais estruturantes e expande-se a zona residencial pela área de Sommerschield a norte, através da criação de alguns bairros, definindo-se em grande parte o contorno final da "cidade de cimento", atual centro urbanizado.

Mendes (1985) acrescenta que esse plano evidencia um profundo desconhecimento da realidade social de Lourenço Marques. Na década de 1950, iniciou-se um crescimento acelerado da cidade, cujo maior impacte se deu ao nível da consolidação e expansão das áreas semiurbanizadas, devido a fatores identificados por Oppenheimer e Raposo (2002), como: (1) as condições do meio rural, que promovem a expulsão e o êxodo das populações (fraco desenvolvimento, reformas agrárias, pressão acrescida sobre a terra, aumento da taxa de fecundidade e diferença de salários entre o campo e a cidade); (2) o desenvolvimento industrial, portuário e ferroviário de Lourenço Marques, que atrai uma crescente mão-de-obra rural e a imigração de colonos portugueses nos anos 1960; e (3) a redução do número de moçambicanos que emigravam para trabalhar nas minas da África do Sul, contribuindo para a sua fixação na capital. 0 plano de 1952 não atende a essa realidade e, segundo Morais (2001), evidencia uma política de segregação, que separa física e culturalmente a "cidade de cimento" e o "caniço", propondo a criação de uma área exterior, adjacente às vias de acesso, para residência da população autóctone.

Em 1963, durante o período de maior crescimento populacional (1960 a 1970) (LOPES; AMADO; MUANAMOHA, 2007), Amâncio Guedes (GUEDES, 1963 apud MORAIS, 2001, p. 240) acusa a existência de uma "cidade doente", na publicação do seu manifesto Manual da Alfabetização do Vogal sem Mestre. Ali, Guedes evidencia o investimento nas zonas nobres da cidade e a inabilidade da Administração Pública para lidar com a situação da área semiurbanizada, prevendo que a mesma "chegará a Marracuene e passará da Matola num sem fim de casinhas e casinhas [somando] aos problemas atuais [...] outros mais graves e infinitamente mais sérios". Segundo o autor, o "caniço" representava já outra cidade, com uma dinâmica própria e um número de habitantes desconhecido, com notória ausência de infraestruturas e equipamentos, de organização espacial irregular, baseada num esquema funcional de vias, caminhos e atalhos, que se transformavam geralmente em ruas cul-de-sac, onde se formava um grande pátio irregular (GUEDES, 1971 apud MORAIS, 2001).

Em face da inadequação do plano de 1952, inicia-se a elaboração do Plano Diretor de Urbanização de Lourenço Marques de 1969 (aprovado em 1972), coordenado pelo engenheiro Mário de Azevedo, num período marcado pela criação do Gabinete de Urbanização da Câmara (1964), destinado a estudar e retificar o plano de 1952 e a elaborar pequenos planos parcelares (MORAIS, 2001); assim como pela exportação de arquitetos portugueses para as colónias por questões políticas. Segundo Lôbo (1995, p. 219), a "ineficiência do plano-imagem decorrente da sua rigidez conduziu à sua substituição pelo plano de gestão mais flexível e suscetível de adaptação durante a implementação, à medida que novas informações assim o exijam". 0 plano foca diferentes escalas territoriais e apresenta preocupações com várias vertentes do urbanismo evolução urbanística, conforto climático, "caniço", tráfego, aspectos demográficos e sociais - para as quais elabora estudos especiais e formula propostas para a organização da cidade, de acordo com diversos usos do solo e a circulação (AZEVEDO, 1969).

Se ao longo dos séculos XIX e XX já se tinham introduzido alterações ao urbanismo português da fase de expansão ultramarina, o plano de 1969 marca a quebra mais visível. Sob influência do Movimento Moderno, esse plano procede a propostas de zonamento e de organização funcional do espaço, apoiadas no sistema viário e baseadas em diagnósticos exaustivos e pluridisciplinares, nos quais aspectos como a malha urbana e os lotes deixam de ser uma preocupação. Morais (2001) refere que este passa a assumir também uma responsabilidade sociocultural, procurando integrar as comunidades plurirraciais pela distribuição do espaço. Assim, as áreas semiurbanizadas são englobadas na área de desenvolvimento urbano, embora "sujeita[s] a um ordenamento sumário, e servida[s] por convenientes acessos e pelas infraestruturas e equipamentos exigidas pelo saneamento da zona 
e vida normal dos seus habitantes" (AZEVEDO, 1969, p. 202). Estas intervenções nunca chegaram a efetivar-se de forma generalizada e significativa e os recursos continuaram a beneficiar maioritariamente o centro urbanizado.

Segundo Morais (2001, p. 186-187), as "décadas de 60 e 70 até à independência foram marcadas pela implementação de uma nova tipologia edificatória na área central da cidade", que reflete as tendências arquitetónicas da época, iniciando-se a substituição do carácter "tropical" [e português] da cidade por uma imagem de metrópole internacional, mais verticalizada, "enquanto a área suburbana se expandia dando origem a novos bairros, alguns de carácter espontâneo" e outros planeados.

\section{A cidade de Maputo pós-independência}

Até meados da década de 1980 Moçambique é dirigido por um partido único de pendor socialista, a Frelimo, e assiste ao recuo drástico da sua economia, determinado pela herança do período colonial, a inoperância do sistema político implementado, a desadequação de algumas políticas e medidas adotadas e a guerra civil iniciada pela Renamo contra a Frelimo (1977-1992). O planeamento urbano deste período é marcado por medidas estruturais como: (1) no III Congresso da Frelimo (1977) são definidas diretrizes para o planeamento e a intervenção no meio urbano e é criada a Direção Nacional de Habitação (DNH) ${ }^{4}$, que desenvolveu algumas ações inovadoras de melhoramento das áreas semiurbanizadas; (2) na I Reunião Nacional sobre Cidades e Bairros Comunais (1979) refletiu-se sobre os problemas urbanos e defenderam-se soluções de autoconstrução, diante da baixa disponibilidade de recursos estatais (Centro de Estudos de Desenvolvimento do Habitat, 2006); e (3) a DNH é convertida no Instituto Nacional de Planificação Física (INPF) (1983), com a competência de definir políticas habitacionais e urbanas e proceder ao planeamento territorial, ficando a sua implementação e a gestão urbana para os então Conselhos Executivos das cidades. Tomam-se também medidas com o objetivo de reduzir a polarização social, como a nacionalização de diversos sectores (educação, saúde, terra e prédios de rendimento), a instalação de equipamentos sociais nos bairros semiurbanizados, o fornecimento estatal de habitações, a melhoria de infraestruturas básicas e algumas intervenções de qualificação urbana (RAPOSO, 2007; ROSÁRIO, 1999).

Em Maputo, as primeiras medidas contemplaram: a inclusão do "caniço" nos limites administrativos da cidade, implicando funções acrescidas para o município, apesar da diminuição de recursos; a implementação exemplar dos projetos de reordenamento participado e flexível em Maxaquene e Polana Caniço, sob iniciativa da DNH e financiamento das Nações Unidas (RAPOSO, 2007); a melhoria de infraestruturas em áreas semiurbanizadas (fontanários públicos, rede elétrica, saneamento e drenagem de águas pluviais), como em Inhangóia/Nsalene (OPPENHEIMER; RAPOSO, 2002); o fornecimento estatal de cerca de 3.000 habitações (1977 a 1985); e a disponibilização de aproximadamente 14.400 talhões para autoconstrução em Maputo e na Matola (1975 e 1985) (PROL, 1992, 1999 apud OPPENHEIMER; RAPOSO, 2002).

Essas medidas contribuíram também para a crescente atração da população aos centros urbanos, acrescidas por fatores como: (1) a saída da comunidade colonial e europeia, associada à nacionalização dos prédios de rendimento, permitindo o acesso de milhares de africanos aos mesmos; (2) a criação de novos postos de trabalho através da reestruturação do aparelho administrativo do Estado e da nacionalização de várias empresas; (3) a subvenção de produtos alimentares; (4) o impacte da guerra civil sobre as comunidades rurais; e (5) o insucesso das reformas agrárias implementadas nos primeiros anos da independência (Oppenheimer e Raposo, 2002). Datam desse período iniciativas para travar o crescimento urbano, como o sistema de "guia e marcha" e a opressiva Operação Produção, lançada em 1983, assente em evacuações forçadas da cidade para o campo dos chamados "improdutivos", com fortes impactes negativos ao nível social, económico e político (OPPENHEIMER; RAPOSO, 2002).

\footnotetext{
4 Segundo Raposo (2007), a DNH foi constituída por meio da conversão do Gabinete de Urbanização e Habitação para a Região de Maputo, criado nos últimos anos do governo colonial.

5 Os "improdutivos" eram todos os que não dispunham ou fossem interceptados sem os documentos de identificação então exigidos, sendo considerados uma fonte de delinquência e instabilidade social (OPPENHEIMER; RAPOSO, 2002).
} 
Todavia, em face do fluxo migratório para as cidades, da falta de recursos económicos, de informações de base e de quadros técnicos para intervir no sector, da burocracia e da excessiva centralização, o acelerado crescimento da capital continuou a fazer-se essencialmente através das áreas semiurbanizadas, agudizando a situação de precariedade existente (RAPOSO, 2007).

Em meados da década de 1980 inicia-se um novo ciclo económico e político no país. Por um lado, assiste-se à abertura à economia de mercado e ao início da liberalização da economia, com a adesão ao Fundo Monetário Internacional e ao Banco Mundial (BM), pela implementação de Programas de Estabilização Económica e Ajustamento Estrutural, que promoveram um crescimento económico irregular e desigual e o aumento da polarização social. Por outro, inicia-se o processo de democratização, a partir da implementação de um regime multipartidário e da descentralização do poder, marcada pela revisão da Constituição (1990), pelo Programa de Reforma dos Órgãos Locais, lançado pelo BM (anos 1990), e pela aprovação da Lei dos Municípios (Lei n. 3/ 1994), revogada pela Lei de Bases das Autarquias (Lei n. 2/1997). Dos instrumentos jurídicos publicados nesse período com impactes sobre o território, destaca-se ainda a Lei de Terras (Decreto-lei n. 19/1997), que apresenta um compromisso entre a jurisdição formal e a tradicional, em que a terra permanece propriedade do Estado.

Em 1985, no quadro do INPF, surge o Plano de Estrutura de Maputo, mas a sua implementação é dificultada por fatores como a falta de recursos e de informação, o dirigismo do Estado e a dificuldade de negociação com os atores. Posteriormente, o INPF é convertido em Secretaria do Estado e mais tarde incorporado no Ministério da Coordenação da Ação Ambiental, passando a designar-se Direção Nacional do Planeamento e Ordenamento do Território, que, apesar da falta de recursos, contribuiu para a formação de técnicos locais e tem apoiado os municípios na elaboração de diversos planos urbanos. Em 1999, conclui-se o Plano de Estrutura da Área Metropolitana de Maputo, elaborado por duas empresas estrangeiras (Arcadis Euroconsult e JTK Associates) e financiado pelo BM, executado numa perspectiva top-down, gerando discussão e polémica na Assembleia Municipal de Maputo, que acabou por não o aprovar (RAPOSO, 2007).
Na primeira década do novo milénio, foram aprovados o Plano de Estrutura Urbana do Município de Maputo (PEUMM) (2008) e os Planos Parciais de Urbanização (PPU) dos bairros mais a norte da cidade (2010), na sequência da publicação da Lei do Ordenamento do Território (Lei n. 19/2007), que os enquadrou, e da implementação do Programa de Desenvolvimento Municipal (PROMAPUTO) em 2007. Esse programa de dez anos, cofinanciado pelo BM e outros doadores, visa melhorar a cobertura e a qualidade dos serviços municipais, através do fortalecimento institucional e do aumento da capacidade financeira, destacando-se várias ações ao nível dos serviços de limpeza, dos sistemas de saneamento e drenagem e das infraestruturas viárias, como a reabilitação da avenida Julius Nyerere. No âmbito desse programa, destaca-se ainda o incipiente orçamento participativo lançado em 2008, atualmente na sua terceira edição, que estabelece um paralelismo com a pioneira experiência brasileira.

À semelhança do plano de 1969, no PEUMM, pouco ou nada se reconhece do urbanismo português dos períodos anteriores. Após uma análise abrangente da capital, o ordenamento do território centra-se em propostas de zonamento e novas centralidades, no estabelecimento de condicionantes e de um esquema de mobilidade urbana, baseado em vias principais, nós e terminais de transportes públicos. Alguns aspectos identificados e previstos (como a nova centralidade do Zimpeto, a ponte para a KaTembe e a Circular) estão a materializar-se lentamente, mas outros foram ultrapassados ou desvirtuados pelo real crescimento da cidade, à semelhança de planos anteriores. Jenkins (2012) associa essa situação ao facto do PEUMM continuar a adotar uma abordagem top-down, muito centrada no papel do Estado ao nível do desenvolvimento urbano, privilegiando ambiciosas aspirações físicas e pouco considerando necessidades sociais, tendências demográficas, a real base económica para a sua implementação e questões de natureza metropolitana. No que refere aos PPU, destaca-se o facto de terem reconhecido as áreas semiurbanizadas ocupadas e edificadas não oficialmente como áreas legítimas a manter.

Desde o início do novo período económico e político até à atualidade, o número de atores envolvidos em diversos tipos de intervenções urbanas é crescente, podendo ou não agir em parceria com entidades do governo central ou local. As agências internacionais, para além das referidas ações ao nível do processo de 
descentralização e da produção de planos urbanísticos, estão ainda associadas a outras, como: o Projeto de Reabilitação Urbana, no início de 1987 (BM); o programa de Endereçamento, com vista a uma melhor gestão municipal (BM e Cooperação Francesa); o programa "Rapid Urban Sector Profiling for Sustainability", em 2004 (UN-HABITAT); o plano para "melhoramento dos assentamentos informais", em 2006 (UN-HABITAT); e o projeto de qualificação do Chamanculo $C$, financiado pela Cities Alliance, em parceria com Brasil, Itália e BM, aprovado em 2011, e que segue uma metodologia integrada de intervenção, incluindo processos de empowerment e a participação da população

As organizações da sociedade civil - organizações não governamentais (ONG) estrangeiras e nacionais, congregações religiosas e organizações comunitárias de base - emergem nas décadas de 1980 e 1990 e também passam a ter um papel ativo em várias intervenções urbanas, particularmente em qualificações pontuais de áreas semiurbanizadas, como: o programa "Pfuka Dzixile" (ONG Associação Moçambicana para o Desenvolvimento Urbano - AMDU, com a participação das comunidades) (ROSÁRIO, 1999); e as intervenções que procuraram envolver a população com base em "comida pelo trabalho" (iniciativa municipal, com cooperação da AMDU e pontualmente da ONG italiana MOLISV) (OPPENHEIMER; RAPOSO, 2002).

Também as ações desenvolvidas numa lógica de mercado por investidores privados, nacionais e internacionais (destacando-se portugueses, brasileiros, chineses e sul-africanos), assumem um peso cada vez maior, principalmente no centro urbanizado, exercendo uma crescente pressão imobiliária sobre as áreas semiurbanizadas mais próximas e também já nas mais afastadas. Assiste-se, por exemplo: à construção de edifícios administrativos, de serviços (centro) e residenciais para classes média e alta (centro, Costa do Sol e Zimpeto), podendo envolver processos de gentrification (Polana Caniço A e Maxaquene A); à construção de habitações subsidiadas pelo Estado (Zimpeto); à formulação de projetos urbanísticos (área da Praça de Touros e Maxaquene A); e à implementação de grandes superfícies comerciais, equipamentos e infraestruturas viárias. No centro, as novas edificações individuais integram-se na malha urbana existente ou implantam-se em áreas não edificadas no período colonial (declivosas ou com um nível freático elevado), cortando nesse caso com o princípio do urbanismo português de adaptação à topografia e respeito pelas condicionantes naturais de cada local. 0 edificado pode ou não substituir construções mais antigas e rompe com a imagem da "cidade portuguesa" pela arquitetura de cariz internacional adotada e pela maior verticalização. Nas áreas semiurbanizadas, essa forma de intervir é acrescida pela maior escala de implantação das superfícies comerciais e dos conjuntos residenciais, deixando de ser evidentes outros princípios do urbanismo português: surgem rupturas entre traçados, a lógica dos quarteirões desaparece, a rua deixa de assumir um papel preponderante e introduzem-se novas tipologias, como os condomínios fechados, entre outros.

Subsistem ainda ações públicas, como: demarcação e disponibilização de talhões com ou sem infraestruturas básicas, fornecimento de habitações evolutivas e de baixo custo e programas de fomento à autoconstrução. Nesse âmbito, os reassentamentos assumem particular relevância, destacando-se os decorrentes de: cheias (sendo mais significativo o de Magoanine C, resultante das cheias de 2000, que contou com a participação de várias organizações da sociedade civil e da população); processos de qualificação de áreas semiurbanizadas mais centrais (Mafalala e Chamanculo C); ou infraestruturas viárias (como a Estrada Nacional n. 4, envolvendo a empresa CMC África Austral).

Nesse contexto de globalização e economia neoliberal dominante, o panorama urbano remete para a existência de várias iniciativas com escalas, níveis e tipos de atuação distintos, implementadas por atores nacionais e internacionais, deixando o planeamento e a gestão urbanos de ser da exclusiva responsabilidade das instituições públicas. Segundo Forjaz (2004[?]), não há capacidade efetiva de coordenação dos diferentes atores e as iniciativas não têm um objetivo definido de conjunto, uma linha de coerência clara entre princípios ideológicos e a

\footnotetext{
6 Esta área não inclui a Ilha da Inhaca e a região da KaTembe, também pertencentes ao Conselho Municipal de Maputo, por terem pouco impacte em termos populacionais e um contributo reduzido para as questões em análise.

7 Ver site do Instituto Nacional de Estatística. Disponível em: <http://www.ine.gov.mz>. Acesso em: 16 ago. 2012.
} 
aplicação prática e um compromisso político relativo aos complexos problemas urbanos existentes, que continuam sem resolução.

Atualmente a cidade de Maputo, com aproximadamente $167 \mathrm{~km}^{2}$ de extensã $0^{6}$, conta com 1.094.628 habitantes (INE, censos de $2007^{7}$ ) e a UN-Habitat (2008, p. 6) estima que 70\% desses habitam áreas semiurbanizadas. 0 crescimento "do caniço", pressentido em 1963 por Amâncio Guedes, confirma-se após independência, sob a insuficiente ação dos governos centrais e locais, envolvendo ou não outros atores, mas principalmente pelas mãos dos seus "residentes construtores", assumindo uma escala no tecido urbano bem mais significativa que o centro urbanizado. A estrutura deste último pouco se alterou desde o período colonial e, apesar da degradação e saturação de algumas áreas e das crescentes novas intervenções de que tem sido palco, continua a constituir-se essencialmente como herança portuguesa ao nível: da sua malha urbana hierarquizada e adaptada ao território, do traçado viário regular, do património edificado desde o período de expansão até ao Movimento Moderno, das suas praças, parques e jardins e do seu reconhecimento enquanto tal por parte da população.

Por sua vez, as áreas semiurbanizadas expandem-se, consolidam-se e densificam-se, repercutindo-se na saturação dos equipamentos e infraestruturas e sua insuficiência, na dificuldade de acesso à educação e à saúde, no desemprego e na economia informal, na pobreza urbana, na emergência de problemas ambientais e sociais, entre outros. Para Raposo e Salvador (2007), essas áreas são a materialização do sincretismo e interação entre o mundo urbano de origem colonial e ocidental, que lhe serve de referência, e o mundo rural moçambicano, principal origem dos seus habitantes, onde os padrões de vida se afastam das referências rurais, mas também não seguem as citadinas do centro. Embora as áreas semiurbanizadas extravasem o limite administrativo da capital, a Figura 4

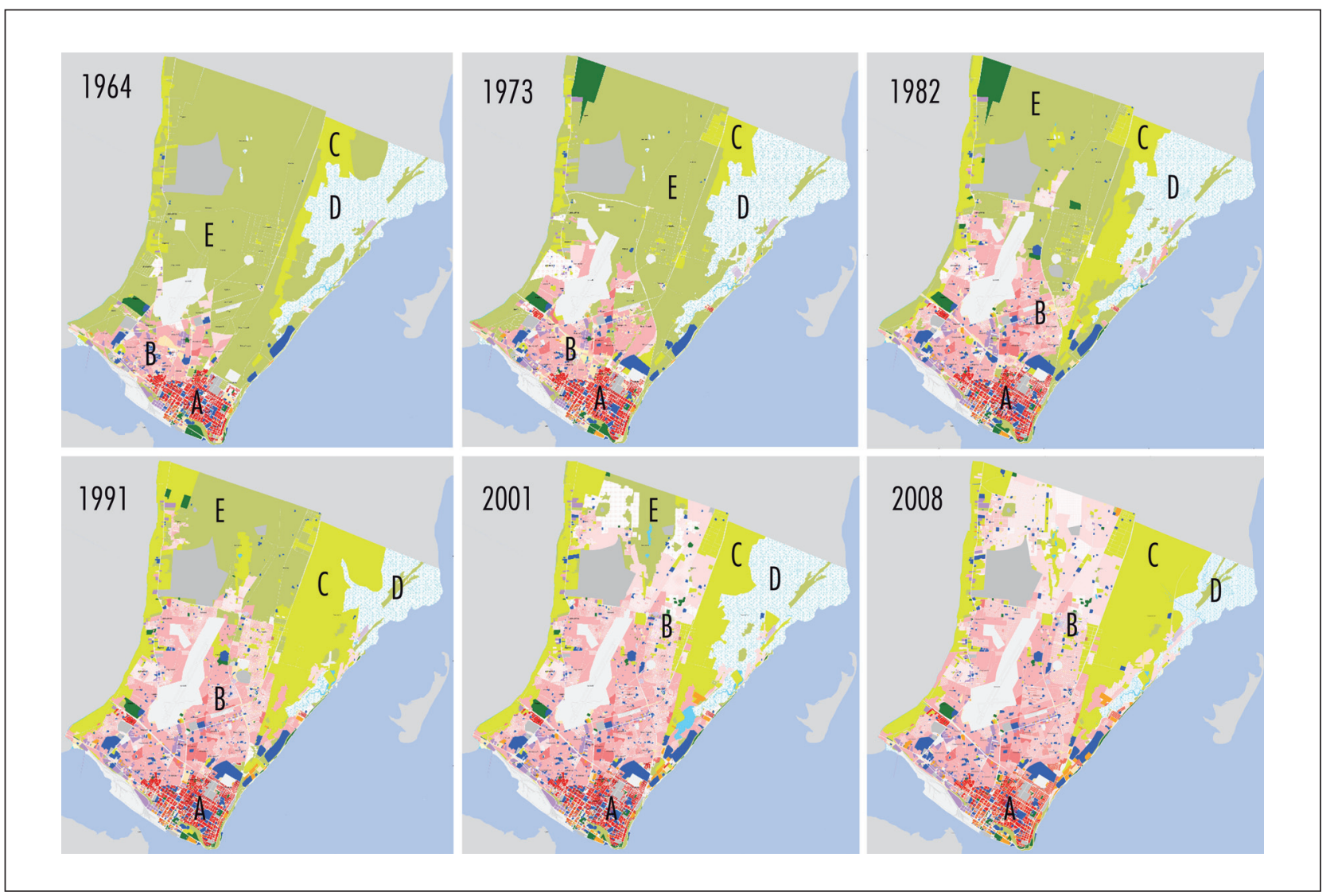

Figura 4 - Centro urbanizado e evolução das áreas semiurbanizadas de Maputo

Legenda: $A=$ = Centro urbanizado; $B$ = Áreas semiurbanizadas; $C=$ Áreas de atividade económica; $D=$ Áreas húmidas e inundáveis; $E$ = Outras áreas naturais, seminaturais, de lazer e vazias. Fonte: Figura elaborada pela autora recorrendo a mapas de Usos do Solo de HENRIQUES, 2008a, b, p. 127). 
assinala apenas as que se encontram dentro desse limite, a sua evolução desde o fim do período colonial até 2008 e o centro urbanizado.

Nas áreas semiurbanizadas criadas por processos oficiais - disponibilização de talhões com ou sem habitação e reassentamentos - é notória a existência de um traçado regulador de geometria ortogonal, cujas vias mais ou menos hierarquizadas conformam diferentes conjuntos de talhões. As áreas semiurbanizadas ocupadas por processos não oficiais apresentam um panorama mais complexo. Nas mais recentes é comum encontrarem-se áreas com um traçado regular, cuja implementação envolve geralmente líderes locais e técnicos municipais (de forma não oficial), e onde, como refere Nielsen (2010), se procura facilitar a legitimação da ocupação ao seguir o modelo das áreas traçadas oficialmente, confundindo-se com as mesmas. Nas áreas mais antigas, a malha orgânica é mais preponderante e assume um cariz mais autóctone, mas também surgem exemplos nas mais recentes. Jenkins e Andersen (2011) mencionam que nessas últimas áreas, previamente ocupadas por residências dispersas, cujos moradores "nativos" detinham direito costumeiro de uso e ocupação sobre territórios relativamente grandes, o parcelamento é feito pelos próprios, materializando-se numa malha orgânica, com o objetivo de dissimular as ocupações posteriores, assemelhando-as às existentes. A Figura 5 ilustra alguns exemplos das diferentes expressões territoriais que podem encontrar-se atualmente na capital moçambicana.

Reflexão crítica: o urbanismo português no presente e no futuro da cidade de Maputo

Para responder às duas questões iniciais foi necessário caracterizar primeiramente como o urbanismo português se manifestou na capital moçambicana. A análise histórica do seu desenvolvimento permite identificar três aspectos que influem essa caracterização e a forma como esta se foi alterando ao longo do tempo: os princípios urbanísticos que regem este urbanismo, o seu processo de concepção e implementação e o contexto em que ele se dá.

Ainda durante o período colonial, os princípios urbanísticos identificados na fase de expansão ultramarina vão sendo sucessivamente alterados, até deixarem de se reconhecer no plano de 1969, que pouco impacte teve já sobre a cidade, e nas intervenções arquitetónicas de cariz internacional que iniciaram no fim do período colonial a verticalização da "cidade de cimento". Após a independência de Moçambique, a expansão de Maputo dá-se essencialmente através da proliferação de contínuas áreas semiurbanizadas, que revelam uma realidade ainda mais diversa, embora se identifique alguma influência da herança urbana portuguesa.

Por um lado, os processos de produção não oficial dessas áreas, particularmente as que assumem uma malha orgânica, são de natureza autóctone, dando-se à margem do urbanismo português desde o período colonial. Por outro lado, nas áreas criadas por processos oficiais, a existência de um traçado regulador de geometria ortogonal, mais ou menos hierarquizado, no qual as vias assumem um papel preponderante na estruturação territorial, remete para um dos princípios mais constantes do urbanismo português; este também relacionado, nesse caso, com a maior facilidade de implantação no terreno, de expansão urbana e de instalação de infraestruturas. Entrevistas efetuadas pela autora a residentes e a outros atores de relevo (informação verbal, 2007 e 2011 a 2013) evidenciam o seu agrado perante este tipo de organização espacial, que associam a uma maior modernidade, desenvolvimento e urbanidade espelhados no centro. A "cidade de cimento" funciona assim como um modelo de referência, quer das intervenções levadas a cabo pelos governos locais, como também de uma parte significativa das ocupações não oficiais mais recentes que as seguem. Contudo, essa característica não representa mais do que uma influência, que se reflete de forma fragmentada no território, sendo incapaz de conferir a essas áreas qualquer identidade urbana relacionada com a "cidade portuguesa".

Ao nível processual identificam-se também dois aspectos semelhantes entre o urbanismo português da fase de expansão ultramarina e a produção das áreas semiurbanizadas: a implementação do traçado não depende de um plano previamente elaborado, baseando-se na ausência do mesmo no conhecimento empírico dos executantes e em modelos de referência; e, à semelhança do que descrevem Teixeira e Valla (1999, p. 220), em "conjuntos urbanos de menor dimensão, as respectivas autoridades municipais apoiavam-se em mestres ou 

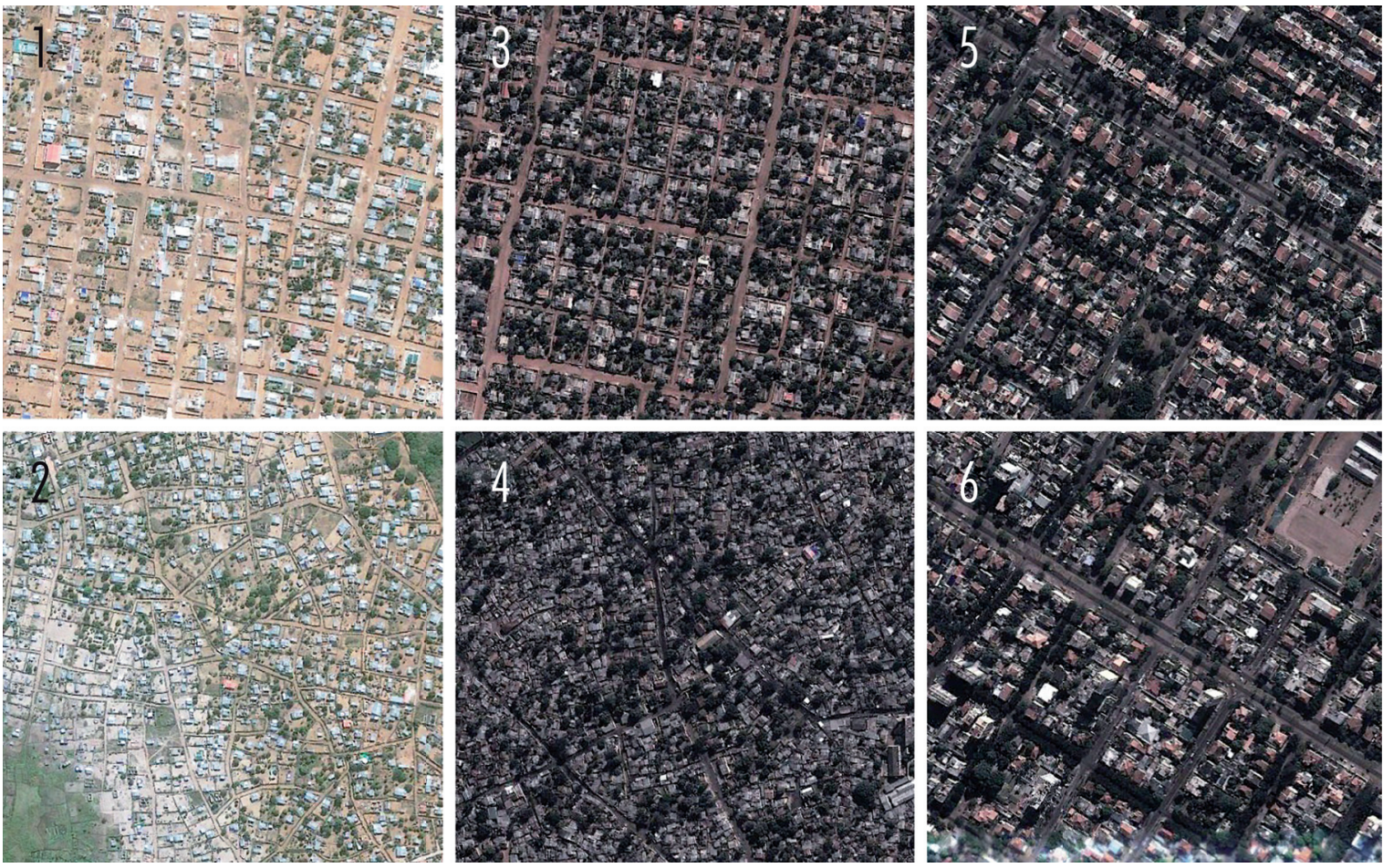

Figura 5 - Exemplos de diferentes expressões territoriais de Maputo

Legenda: 1, 2 = Áreas semiurbanizadas mais afastadas do centro urbanizado; 3, 4 = Áreas semiurbanizadas mais próximas do centro urbanizado; 2 e 4 = Áreas sermiurbanizadas orgânicas de ocupaç̣̃o não oficial; 1,3 = Áreas semiurbanizadas regulares de ocupação oficial ou nõo; 5, 6 = Centro urbanizado.

Fonte: Figura elaborada pela autora com base em fotografias aéreas recolhidas no Google Earth ${ }^{8}$.

arruadores" para implementação do traçado ou esta podia ser "da responsabilidade dos habitantes mais hábeis ou mais qualificados" (TEIXEIRA; VALLA, 1999 , p. 258), que no caso das áreas semiurbanizadas remete para a participação oficial ou não de líderes locais, técnicos municipais e da população na demarcação de vias e talhões. No entanto, em face da distância temporal, essas semelhanças processuais não pressupõem a existência de uma influência, mas antes um modo de agir que se adapta similarmente às contingências contextuais específicas de cada época.

Ao longo do tempo, a implementação do urbanismo português foi assumindo um carácter mais normativo; quando o desenho passa a ter um papel preponderante. 0 planeamento torna-se cada vez mais centralizado (de abordagem top-down), baseado em conhecimentos técnicos e científicos, procurando controlar e regulamentar o desenvolvimento urbano. Após 1975, esse tipo de abordagem permaneceu na maioria dos planos elaborados, como o de 1999 e o PEUMM. Todavia, esse tipo de planeamento tem vindo a ser contestado desde a década de 1960 e, em contexto africano, Jenkins, Smith e Wang (2007) criticam: (1) a reduzida relação com questões sociais, económicas e ambientais; (2) a desadequação às forças de mudança e crescimento rápidos que caracterizam o desenvolvimento urbano, tornando-se os planos rapidamente obsoletos; (3) os padrões ocidentais que os norteiam e não se adequam à natureza das áreas semiurbanizadas e às necessidades das comunidades locais, assim como subestimam a

\footnotetext{
${ }^{8}$ Disponível em: <earth.google.com.br/>. Acesso em: 10 ago. 2012.
} 
reduzida capacidade financeira, legislativa e administrativa dos governos para os implementar; e (4) a fraca interligação institucional e entre interesses políticos, decisões orçamentais dos governos locais e outras entidades envolvidas no processo urbano.

Dessas contestações têm emergido propostas alternativas de planeamento à escala global (como o planeamento estrutural, o plano ação, a gestão do solo e infraestruturas e por negociação), algumas das quais contemplam processos de empowerment das comunidades. Estes tornam-se particularmente importantes em contextos de grande desigualdade socioeconómica e política, como o de Maputo, por promoverem o equilíbrio das iniquidades que se repercutem no espaço urbano, como refere Friedmann (1992), e estão intimamente relacionados com questões inerentes ao planeamento participativo, à participação dos cidadãos no assunto público, à problemática da democracia representativa, participada e inclusiva.

Os projetos de reordenamento participado e flexível em Maxaquene e Polana Caniço, implementados logo após a independência com o financiamento das Nações Unidas, cortam com a tradição desse planeamento centralizado, normativo e tecnocrata e estabelecem um paralelo com a experiência do Serviço de Apoio Ambulatório Local, implementado em Portugal entre 1974 e 1976, cujas intervenções de planeamento e qualificação em áreas semiurbanizadas contavam com a participação da população. Esse paralelismo não é alheio a um contexto de recente libertação de regimes políticos repressivos (Portugal após o fim da ditadura e Moçambique em seguida independente), associada a um forte dinamismo popular. Esse tipo de abordagem voltará a estar presente nas intervenções urbanas que ocorrem após meados da década de 1980 com a participação de organizações da sociedade civil ("Pfuka Dzixile", as intervenções com base em "comida pelo trabalho" e o reassentamento de Magoanine C) e de agências internacionais (o projeto de qualificação do Chamanculo C e o orçamento participativo), sendo os moçambicanos e os brasileiros os atores lusófonos mais presentes.

As várias ideologias do Estado português durante a fase de expansão ultramarina, a Revolução Industrial e o Estado Novo, bem como as necessidades específicas inerentes a cada um desses contextos, assumem um papel preponderante na forma como é concebido e alterado o urbanismo português ao longo do tempo. Como referido, a influência de modelos internacionais também contribuiu para a sua progressiva reconfiguração e é com o Movimento Moderno que este praticamente se desvanece. Essa influência retrocede após a independência de Moçambique, durante o período socialista, mas retorna com viragem económica e política de meados dos anos 1980, assumindo um papel cada vez mais preponderante em pleno contexto de globalização e de economia neoliberal dominante. Como referem Jenkins, Smith e Wang (2007, p. 26), "cities will be reshaped by global economic forces over the course of this century" e esta reconfiguração processa-se através de um intrincado jogo de interesses, atores e diferentes formas de intervir, onde o Estado se reconfigura e tende a privilegiar o interesse económico em detrimento do social (SASSEN, 2003). Em Moçambique, a atuação do governo central e local e a sua capacidade de gerir e coordenar as ações do crescente número de atores e seus interesses, apresenta atualmente ainda maior fragilidade devido a fatores como: a extrema juventude do processo político, a má governação (sob a forma de corrupção, falta de transparência e responsabilidade social, de ausência de compromisso político e de coerência entre princípios e práticas, entre outros), as limitações de competências e recursos e a dependência da ajuda externa.

Nesse contexto, a influência das agências internacionais e de organizações da sociedade civil ao nível do planeamento da cidade, da sua gestão e das intervenções urbanas é notória, centrando-se geralmente nos problemas das áreas semiurbanizadas, embora com insuficiente eficácia. Todavia, são as intervenções efetuadas numa lógica de mercado por investidores privados que têm maior impacte ao nível do território, evidenciando também as maiores rupturas com a herança urbana portuguesa. Estas estão associadas às novas aspirações socioeconómicas e culturais da sociedade moçambicana, em especial das elites, introduzidas e crescentemente promovidas em contexto de globalização, bem como aos novos modelos arquitetónicos e urbanísticos internacionais que as vinculam e são usados pelos investidores sob várias influências. Essas intervenções com vista ao lucro, pouco têm contribuído para a resolução dos problemas urbanos que afetam as extensas áreas semiurbanizadas, tendendo antes a promover o aumento da segregação socioespacial (JENKINS; WILKINSON, 2002; RAPOSO, 2007). 
É nesse panorama que ainda prevalecem no centro urbanizado os princípios do urbanismo português que marcam a sua génese e a maior parte do seu desenvolvimento. Aqui, a existência de uma cidade de origem portuguesa intui-se, entre outros fatores, na sua relação com as particularidades geográficas locais, na estrutura urbana hierarquizada e delineada pelo traçado regular das suas vias, pela forma como este se articula com o conjunto de parques e jardins, com os equipamentos marcantes e com o ainda grande património edificado nesse período. Esse legado, reconhecido pela população, alicerça essa cidade africana num passado histórico singular, conferindo-lhe uma memória e riqueza cultural únicas, que fazem parte da sua identidade e, que na África Austral, apenas encontra paralelo em outras cidades lusófonas.

Contudo, o seu surgimento deu-se pela ligação colonial a Portugal e quase sempre à margem ou negligenciando a cultura e as necessidades da população local. Finda essa ligação, e sendo Maputo o reflexo de um contexto extremamente complexo, distinto dos demais, com caraterísticas socioeconómicas, culturais e políticas próprias e com necessidades e problemas específicos, impõem-se desafios urbanísticos diferentes dos que moldaram ao longo do tempo o urbanismo português. Para Parker (2004, p. 164), as cidades com elevados níveis de suburbanização requerem novas abordagens e não devem ser entendidas como "the untamed past of modernity's future [mas] as the untamed future of modernity's present". No caso de Moçambique, Forjaz (2004[?]) refere que o problema é encontrar um novo modelo urbano, sem exemplo na história das cidades ou da civilização, adequado ao seu contexto específico.

Diante desse cenário, poder-se-ia referir que o papel mais preponderante do urbanismo português atualmente em Maputo se dá ao nível da memória, da cultura e da identidade da cidade, podendo questionar-se a validade e adequação de alguns dos seus princípios e processos (como os que ainda hoje se pressentem na produção de algumas áreas semiurbanizadas) no seu desenvolvimento futuro, eventualmente adaptados e conjugados com outros, de forma a produzirem respostas mais eficazes aos problemas da cidade. Contudo, no atual contexto de globalização e economia neoliberal dominante, em presença de uma complexa rede de influências e interesses, a lógica da produção capitalista do espaço é cada vez mais prevalecente. Esta segue novas aspirações socioculturais e rompe simultaneamente com a herança urbana portuguesa e com um modo mais endógeno de habitar e produzir o espaço, não respondendo também aos problemas das áreas semiurbanizadas. Nesse panorama urbano complexo e imprevisível, o legado do urbanismo português continua a adaptar-se ao novo consórcio de ideias urbanas vigente, onde as lusófonas se esbatem entre as de outras proveniências, mas a perspectiva futura desta significativa herança urbana portuguesa em África torna-se incerta.

\section{Conclusão}

A presença colonial portuguesa em África foi mais duradoura que em outras regiões, permitindo sedimentar até mais tarde a sua herança urbana. Contudo, é ainda nesse período que os princípios do urbanismo português da fase de expansão, que veicularam de forma mais contundente a identidade da "cidade portuguesa", se começam a desmontar, adaptando-se a novos contextos e incorporando influências exteriores, sendo mais decisivas as que advieram do Movimento Moderno. Após a independência de Moçambique, a consolidação e imensa expansão das áreas semiurbanizadas, já iniciada no período colonial à margem do centro planeado e edificado pelos portugueses, apresenta a maior ruptura com esta tradição, assumindo um modo de produção, uma configuração e uma identidade muito próprios.

O contexto que marca atualmente a capital moçambicana é muito distinto dos que marcaram o urbanismo português, tal como é muito diferente a natureza dos problemas urbanos nela patentes, evidentes, sobretudo na pobreza e na falta de habitat condigno que se espelham nas áreas semiurbanizadas, para os quais é necessário encontrar um novo modelo urbano. Nessa procura, pode considerar-se a validade de alguns princípios e processos associados ao urbanismo português, como aqueles ainda hoje presentes na produção das áreas semiurbanizadas, sendo que as experiências emancipadoras que surgem após a independência, contemplando o empowerment e a participação das comunidades, prestam também um válido contributo. Essas refletem a influência de agências internacionais e organizações da sociedade civil, bem como de um consórcio de ideias lusófonas, distanciando-se da abordagem centralizada, normativa 
e tecnocrata dos planos coloniais, patente também na maioria dos produzidos após 1975.

Atualmente o papel mais significativo da herança urbana portuguesa coloca-se ao nível da memória da cidade e da sua riqueza cultural, que contribuem para a sua identidade singular no panorama da África Austral, apenas presente em outras cidades lusófonas. A cisão com o urbanismo português no período socialista após a independência, decorrente das alterações e limitações contextuais, não colocaram em causa esta herança. Contudo, a emergência de novos atores após a viragem económica e política de meados da década de 1980 e a crescente preponderância das suas intervenções em pleno contexto de globalização e economia neoliberal dominante, vem tornar incerto o futuro da mesma. Sob um Estado reconfigurado com várias fragilidades de atuação, a lógica da produção capitalista do espaço assume um papel cada vez maior, respondendo a aspirações que se enquadram em modelos de referência internacionais, difundidos sob uma grande variedade de fluxos de influência, nas quais as lusófonas se esbatem. Se, por um lado, os problemas urbanos mais prementes da maioria da população da capital continuam por atender, por outro, vai-se comprometendo o legado da "cidade portuguesa".

\section{Referências}

AZEVEDO, M. O Plano Director de Urbanização de Lourenço Marques. Separata do Boletim n. 7 da Câmara Municipal de Lourenço Marques. Lourenço Marques: Câmara Municipal, 1969.

CABRAL, J. P. A Catedral das Palhotas: religião e política no Moçambique Tardo-Colonial. 2005. Disponível em: <http://www.ics.ul.pt/corpocientifico/pinacabral/pdf/ sabatica/apendviii.pdf>. Acesso em: 12 jul. 2007.

CENTRO DE ESTUDOS DE DESENVOLVIMENTO DO HABITAT. Melhoramento dos assentamentos informais, análise da situação \& proposta de estratégia de intervenção. Maputo: Direcção Nacional de Planeamento e Ordenamento Territorial (DINAPOT); Ministério para a Coordenação da Acção Ambiental (MICOA). 2006. Disponível em: <http://www.sarpn.org.za/documents/ d0002452/Mozambique_cities_slums_2006_Portuguese. pdf>. Acesso em: 22 jun. 2007.
COSTA, J. P. Bairro de Alvalade. Um Paradigma no urbanismo português. Lisboa: Livros Horizonte, 2002.

ENDERS, A. História da África Lusófona. Mem Martins: Editorial Inquérito, 1997.

FORJAZ, J. Gestão dos recursos naturais e política ambiental. 2004[?]. Disponível em: <http://www.joseforjazarquitectos.com/textos/gestao.html>. Acesso em: 28 fev. 2013.

FRIEDMANN, J. Empowerment: the politics of alternative development. Oxford: Blackwell, 1992.

HENRIQUES, C. Cartas de uso de solo. 2008a. Disponível em: <http://cdh.fa.utl.pt/sig_maputo.html>. Acesso em: 28 fev. 2013.

HENRIQUES, C. Maputo. Cinco décadas de mudança territorial. Lisboa: Instituto Português de Apoio ao Desenvolvimento, Ministério dos Negócios Estrangeiros, $2008 b$.

JENKINS, P. Programa de pesquisa compreender o 'espaço do lar' na cidade africana de Maputo. In: WORKSHOP "HOME SPACE" COMPREENDER O "ESPAÇO DO LAR" NA CIDADE AFRICANA, 2010, Maputo. Relatório de Contexto... Maputo, 2010.

JENKINS, P;; ANDERSEN, J. Developing cities in between the formal and informal. In: EUROPEAN CONFERENCE ON AFRICAN STUDIES - ECAS, 4., 2011, Uppsala. Anais... Available at: <http://www.nai.uu.se/ecas-4/ panels/81-100/panel-85/Jenkins-and-Eskemose-Fullpaper.pdf>. Access on: Jun. 20th. 2011.

JENKINS, P.; SMITH, H.; WANG, Y. P. Planning and housing in the rapidly urbanising world. London: Routledge, 2007.

JENKINS, P.; WILKINSON, P. Assessing the growing impact of the global economy on urban development in southern African cities: case studies in Maputo and Cape Town. Cities, v. 19, n. 1, p. 33-47, 2002. doi:10.1016/ S0264-2751(01)00044-0.

LÔBO, M. S. Planos de urbanização. A época de Duarte Pacheco. 2. ed. Porto: DGOTDU/FAUP, 1995.

LOPES, C. M.; AMADO, F.; MUANAMOHA, R. C. Dinâmica do crescimento populacional em Luanda e Maputo. In: OPPENHEIMER, J.; RAPOSO, I. (Coord.). Subúrbios Luanda e Maputo. Lisboa: Edições Colibri, 2007. p. 37-64. 
MENDES, M. C. Maputo antes da independência: geografia de uma cidade colonial. Lisboa: Instituto de Investigação Científica Tropical, 1985.

MENDES, M. C. et al. Os planos urbanísticos no contexto africano: a experiência portuguesa. Ur Cadernos da Faculdade de Arquitectura da Universidade Técnica de Lisboa: Cidades Africanas, n. 5, p. 40-47, 2005.

MOÇAMBIQUE. Decreto-lei n. 19/1997. Lei de Terras (1997). Diário da República. Maputo, 1997.

MORAIS, J. S. Maputo: património da estrutura e forma urbana. Lisboa: Livros Horizonte, 2001.

NIELSEN, M. Mimesis of the State: from natural disasters to urban citizenship on the outskirts of Maputo, Mozambique. Social Analysis. v. 54, n. 3, p. 153-173, 2010. doi:10.3167/sa.2010.540310.

OPPENHEIMER, J.; RAPOSO, I. A pobreza em Maputo. Lisboa: Ministério do Trabalho e da Solidariedade, Departamento de Cooperação, 2002.

PARKER, S. Urban theory and the urban experience: encountering the city. London: Routledge, 2004.

PORTAS, N. Interrogações sobre as especificidades das fundações urbanas portuguesas. In: PORTAS, N. Os tempos das formas: a cidade feita e refeita. Guimarães: Universidade do Minho, 2005. p. 15-46. v. 1.

RAPOSO, I. Instrumentos e práticas de planeamento e gestão dos bairros peri-urbanos de Luanda e Maputo. In: OPPENHEIMER, J.; RAPOSO, I. (Coord.). Subúrbios Luanda e Maputo. Lisboa: Edições Colibri, 2007.p. 219-246.

RAPOSO, I.; SALVADOR, C. Há diferença: ali é cidade, aqui é subúrbio: urbanidade dos bairros, tipos e estratégias de habitação em Luanda e Maputo. In: OPPENHEIMER, J.; RAPOSO, I. (Coord.). Subúrbios Luanda e Maputo. Lisboa: Edições Colibri, 2007. p. 105-138.
ROSÁRIO, M. A. Participatory development \& urban management. In: FERRAZ, B.; MUNSLOW, B. (Ed.). Sustainable development in Mozambique. Oxford: MICOA, James Currey, Africa World Press, 1999. p. 183-201.

ROSSA, W. A urbe e o traço. Uma década de estudos sobre o urbanismo português. [S.l.]: Almedina, 2002.

SASSEN, S. The Participation of states and citizens in global governance. Indiana Journal of Global Legal Studies. v. 10, n. 5, p. 5-28, 2003. doi:10.2979/GLS.2003.10.1.5.

TEIXEIRA, M. C. A história urbana em Portugal. Desenvolvimentos recentes. Análise Social, v. 28, n. 2, p. 371-390, 1993.

TEIXEIRA, M. C.; VALLA, M. 0 urbanismo português séculos XIII-XVIII Portugal-Brasil. [S.I.]: Livros Horizonte, 1999.

UN-HABITAT. Mozambique urban sector profile. 2008. Disponível em: <http://www.google.co.mz/url?sa=t\&rct=j $\& q=\&$ esrc $=s \&$ source $=$ web \&cd $=1 \&$ ved $=0$ CDEQFjAA\&url $=\mathrm{h}$ ttp\%3A\%2F\%2Fwww.unhabitat.org\%2Fpmss\%2FgetElec tronicVersion.aspx\%3Fnr\%3D2786\%26alt\%3D1\&ei=bNZ mUe6NI4PEPc2RgOAN\&usg=AFQjCNH-2uRkMlomesauiq bdczJLspLghQ\&bvm=bv.45107431,d.ZWU>. Acesso em: 11 abr. 2013.

Recebido: 30/05/2012

Received: 05/30/2012

Aprovado: 30/10/2012

Approved: 10/30/2012 